\section{Factors Associated with Not Drinking Alcoholic Beverages in Dependent Individuals on Recovery}

Linda Azucena Rodríguez Puente ${ }^{1}$ Fani Villa Rivas ${ }^{2}$

Eva Kerena Hernández Martínez ${ }^{3}$ Raúl Adrián Castillo Vargas ${ }^{4}$ Dafne Astrid Gómez Melasio 5 Edna Idalia Paulina Navarro Oliva ${ }^{6}$

\section{Factors Associated to Not Drinking} Alcoholic Beverages in Dependent Individuals on Recovery

Objective. This work sought to determine the association between personal factors and not drinking alcoholic beverages in alcohol-dependent individuals on recovery process. Methods. This was a cross-sectional quantitative study. The sample was comprised by 119 adult belonging to 50 Alcoholics Anonymous groups in Saltillo, Coahuila (Mexico). The sampling was simple random, by conglomerates (AA groups). To gather the information, a Personal Data Card was used along with a history on alcohol consumption and the instruments Scale on Social Readjustment Classification, Spiritual Perspective Scale, Schwartz Values Survey, and the Alcohol Use Disorders Identification Test (AUDIT). Results. The time without alcohol consumption was related positively with age $(r=0.59)$ and spirituality $(r=0.29)$ and negatively with stressful events $(r=-0.31)$. The Multiple Linear Regression

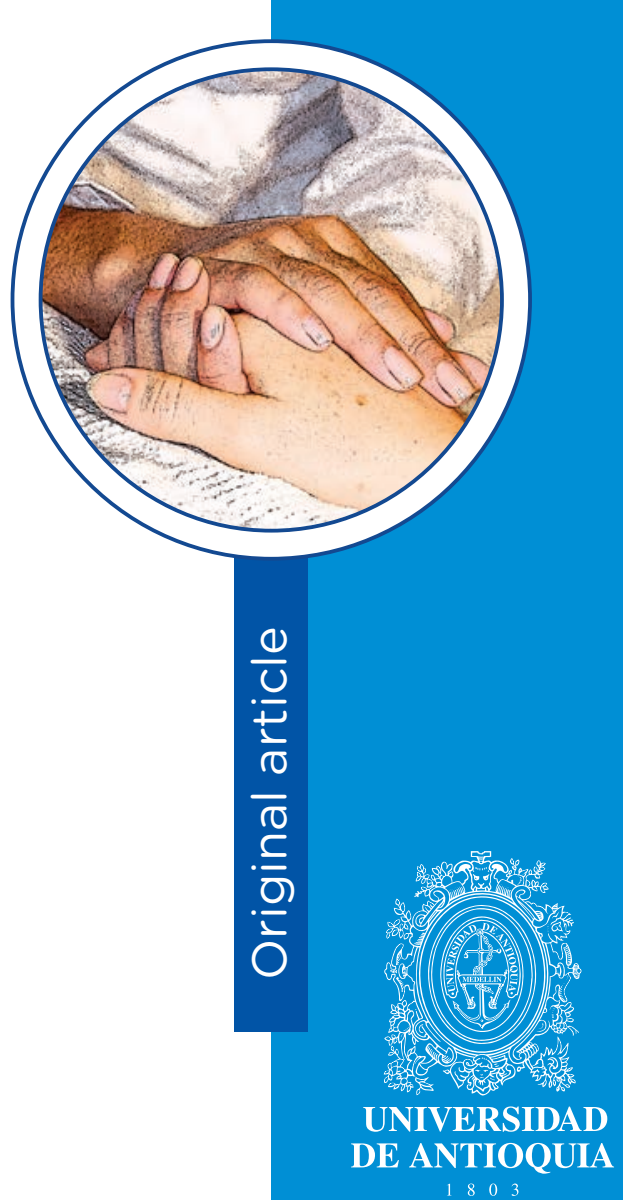

1 Nurse, Ph.D. Professor, Universidad Autónoma de Coahuila, México.

email: Irpuente88@hotmail.com

2 Nurse, Ph.D. Professor, Universidad Juárez del Estado de Durango, México. email: f74villa@yahoo.com.mx

3 Nurse, M.Sc. Professor, Universidad Autónoma de Coahuila, México.

email: kerena con k@hotmail.com

4 Nurse, M.Sc. Director, Universidad Autónoma de Coahuila, México. email: ravargas0125@hotmail.com

5 Nurse, M.Sc. Professor, Universidad Autónoma de Coahuila, México.

email: Dafne.pg@hotmail.com

6 Nurse, Ph.D. Professor, Universidad Autónoma de Coahuila, México.

email: eipno@yahoo.com.mx (Corresponding Author).

Conflicts of interest: none

Received: June 18th, 2018.

Accepted: September 19th, 2018

How to cite this article: Rodríguez LA, Villa F, Hernández EK, Castillo RA, Gómez DA, Navarro EIP. Factors Associated to Not Drinking Alcoholic Beverages in Dependent Individuals on Recovery. Invest. Educ. Enferm. 2018; 36(3):e07. DOI: 10.17533/udea.iee.v36n3e07

\section{(c)(1)(0)}


Model explained $32.5 \%$ of the variance, with age being the variable remaining in the model and which affected not drinking alcoholic beverages. Conclusion. Values and spirituality favor not drinking alcoholic beverages in individuals in the process of recovering from the dependence, while exposure to stressful events increases vulnerability to alcohol consumption.

Descriptors: alcoholics anonymous; linear models; social values; alcohol drinking; surveys and questionnaires.

\section{Factores Asociados al No Consumo de Alcohol en Personas Dependientes en Recuperación}

Objetivo. Determinar la asociación entre los factores personales y el no consumo de alcohol en personas dependientes en proceso de recuperación. Métodos. Estudio cuantitativo, de corte transversal. La población estuvo conformada por 119 adultos pertenecientes a los 50 grupos de Alcohólicos Anónimos de Saltillo, Coahuila (México). El muestreo fue aleatorio simple, por conglomerados (grupos AA). Para la recolección de la información se utilizó una Cédula de Datos Personales e Historial de Consumo de Alcohol y los instrumentos Escala de Clasificación de Reajuste Social, Escala de Perspectiva Espiritual, Cuestionario de Valores Schwarts y Cuestionario de Identificación de los Trastornos debidos al Consumo Alcohol (AUDIT). Resultados. El tiempo sin consumo de alcohol se relacionó en forma positiva con la edad $(r=0.59)$ y con la espiritualidad $(r=0.29)$ y en forma negativa con los eventos estresantes $(r=-0.31)$. El Modelo de Regresión Lineal Múltiple explicó el $32.5 \%$ de la varianza, siendo la edad la variable que se mantuvo en el modelo y tuvo efecto sobre el no consumo de alcohol. Conclusión. Los valores y la espiritualidad favorecen el no consumo de alcohol en las personas en proceso de 
recuperación de su dependencia, mientras que la exposición a eventos estresantes aumenta la vulnerabilidad al consumo.

Descriptores: alcohólicos anónimos; espiritualidad, modelos lineales; valores sociales; consumo de bebidas alcohólicas; encuestas y cuestionarios.

\section{Fatores Associados ao Não Consumo de Álcool em Pessoas Dependentes em Recuperação}

Objetivo. Determinar a associação entre os fatores pessoais e o não consumo de álcool em pessoas dependentes de álcool em processo de recuperação. Métodos. Estudo quantitativo, de corte transversal. A amostra esteve conformada por 119 adultos pertencentes aos 50 grupos de Alcoólicos Anônimos de Saltillo, Coahuila (México). A amostragem foi aleatória simples, por conglomerados (grupos AA). Para a recolecção da informação se utilizou uma Cédula de Dados Pessoais e Historial de Consumo de Álcool e os instrumentos Escala de Classificação de Reajuste Social, Escala de Perspectiva Espiritual, Questionário de Valores Schwarts e Questionário de Identificação dos Transtornos devidos ao Consumo Álcool (AUDIT). Resultados. 0 tempo sem consumo de álcool se relacionou em forma positiva com a idade $(r=0.59)$ e com a espiritualidade ( $r=0.29)$ e em forma negativa com os eventos estressantes ( $r=-0.31$ ). O Modelo de Regressão Lineal Múltiplo explicou 32.5\% da variação, sendo a idade a variável que se manteve no modelo e teve efeito sobre o não consumo de álcool. Conclusão. Os valores e a espiritualidade favorecem o não consumo de álcool nas pessoas em processo de recuperação da dependência, enquanto que a exposição a eventos estressantes aumenta a vulnerabilidade ao consumo.

Descritores: alcoólicos anônimos; espiritualidade; modelos lineares; valores sociais; consumo de bebidas alcoólicas; inquéritos e questionários. 


\section{Introduction}

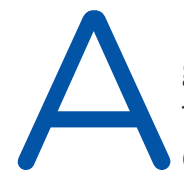

Icohol consumption causes serious repercussions for public health, given that it occupies the third place among the risk factors for falling ill. Harmful alcohol consumption is responsible for the deaths of 3.3-million people annually and for $5.1 \%$ of diseases and lesions globally. ${ }^{(1)}$ According to the National Survey on the Consumption of Drugs, Alcohol, and Tobacco 2016-2017, (2) alcohol consumption in Mexico is considered the first risk factor for the development of over 64 diseases and it is responsible for $6.5 \%$ of premature deaths. Additionally, reports indicate that $71 \%$ of the Mexican population has consumed alcohol at some point of their lives, of which $2.2 \%$ developed alcohol dependence. ${ }^{(2)}$

Alcohol dependence and the limitations during the recovery process may be related with multiple personal, interpersonal, and environmental risk factors. ${ }^{(3)}$ Among the personal factors, stressful events in life are highlighted, ${ }^{(4)}$ having the potential to trigger the consumption of substances, among them alcohol. Furthermore, these vary in severity and are perceived by individuals according to the type of life experience; based on this, the events can be considered by individuals as positive or negative. ${ }^{(5)} \mathrm{A}$ factor highly related to not drinking alcoholic beverages, ${ }^{(1)}$ which is defined as the intake of alcoholic beverages and with recovery from dependence is spirituality. ${ }^{(6-8)}$ Spirituality is defined as the personal perspective and behaviors that express the sense of belonging to a transcendent dimension or something bigger than oneself. ${ }^{(9)}$ In this sense, evidence shows that not drinking alcohol is related with spirituality ${ }^{(6-8)}$ and religious practices. ${ }^{(10,11)}$

Other factors associated with abstinence are some personal factors, among them stimulation, hedonism, pleasure, social power, being daring, and enjoying life are related with excessive drinking of alcohol, while other factors, like national security, internal harmony, equality, union with nature, being loyal, healthy, clean, and helping are shown as protectors of alcohol consumption. ${ }^{(12,13)}$ Some personal factors have been related with dependent consumption of alcohol: early onset of consumption is associated with abuse at later ages, ${ }^{(14-16)}$ greater consumption exists in men than in women; ${ }^{(2)}$ likewise, greater consumption is observed in low socioeconomic levels ${ }^{(17)}$ and those with low educational levels. (17) Based on the aforementioned, the need becomes evident to study from the nursing perspective the phenomenon of recovering from alcohol dependence and achieving abstinence or sobriety. It is considered a relevant area of nursing intervention focused on supporting the recovery process and, thus, contributing to the individual's wellbeing. According to the literature review, studies are insufficient on the phenomenon of alcohol dependence, as well as the recovery and maintenance of abstinence or sobriety by nursing professionals. ${ }^{(12-16)}$

Due to the aforementioned, the purpose of this study was to determine the association of the personal factors (age, stressful events, spirituality, and 
values) and not drinking alcoholic beverages (number of days without consumption) in alcoholdependent individuals on recovery process from the city of Saltillo, Coahuila (Mexico).

\section{Methodology}

This was a cross-sectional, descriptive study of quantitative approach conducted in 2018. The population was comprised by 498 members of the AA program in the city of Saltillo, Mexico. Simple random sampling through conglomerate was carried out (20 groups from the AA program), group selection was through the table of random numbers; of the participants selected principally, six did not wish to participate, mentioning the following reasons: lack of time $(n=4)$ and not interested in participating $(n=2)$. A sample was calculated for a linear regression test with correlation coefficient, $r^{2}=0.652^{(6)}$ with $95 \% \mathrm{Cl}$, with an estimation limit of 0.04 , power of $90 \%$ and considering a $5 \%$ rate of non-response. Sample size was 119 adults belonging to the AA program.

To gather information, the following were used: a) Personal Data Card and History of Alcohol consumption (CDPHCA, for the term in Spanish) and four instruments. The CDPHCA was divided into three sections, i.e., personal data, history of alcohol consumption, and prevalence of alcohol consumption. b) The Scale of Social Readjustment Classification (ECRS, for the term in Spanish) has a classification that indicates the degree of stress or social readjustment necessary when it occurs and ranges from 100 for the most stressful event to 11 for the least stressful and the values of each event occurring during a year will be added; in case an of an event having occurred more than once in the last year, the value is multiplied by the number of occurrences, ${ }^{(18)}$ was validated for the Mexican population. ${ }^{(19)}$ c) The Spiritual Perspective Scale (SPS) developed and translated into Spanish by Reed, ${ }^{(9)}$ measures knowledge of oneself, to a sense of connection with a being of superior nature or to the existence of a supreme purpose. This instrument has a subscale denominated spiritual practices (1 to 4 ) and another subscale denominated spiritual beliefs (from 5 to 10); both are scored in a range from 1 to 6 , for a total score of 24 for the first subscale and 36 for the second. Indices were obtained from each subscale and from the scale in general, where higher scores indicate a higher spirituality index. d) The Schwartz Value Survey ${ }^{(20)}$ measures 56 values, stemming from 10 dimensions; each item is valued as not important, moderately important, and very important. Indices were obtained for each subscale and from the questionnaire in general, where higher scores indicate higher index of values. e) The Alcohol Use Disorders Identification Test (AUDIT) with results ranging from 0 to 40 points; the score from 1 to 3 points is considered sensible consumption (without risk); the result from 4 to 7 points is considered dependent consumption (of risk), and the report of 8 or more points is considered damaging consumption (harmful). ${ }^{(21)}$

This study was approved by the Commission on Research Ethics. Each of the AA centers selected were visited to request authorization from each group and to explain to its members the object of the study. Thereafter, a second visit was made on the date and hour assigned by the AA group, and those who accepted participation were given the informed consent, thereafter, in a sealed envelope, the instruments were provided and the questionnaires were filled out, indicating that the research was confidential in nature and that the information was provided anonymously. Descriptive and inferential statistics were used to analyze the data. Descriptive analysis of the continuous and categorical variables was performed through frequencies, proportions, and central tendency and variability measures, as well as inferential statistics for the objectives. The Kolmogorov-Smirnov goodness-of-fit test was conducted with Lilliefors correction to determine the distribution of the continuous variables. Given that the study variables (indices of stressful events, spirituality, values, and alcohol consumption) did not show normality, the Spearman Correlation Coefficient test was used along with a simple linear regression model with bootstrap, which 
considered age, gender, schooling, and indices of stressful events, spirituality and values as independent variables and not drinking alcoholic beverages (number of days without consumption) as dependent variable.

\section{Results}

This study had the participation of 119 adults belonging to AA groups. Regarding sociodemographic data, $86.6 \%$ were males, $43.7 \%$ were married, $26.9 \%$ had attended school to secondary level, most worked (69.7\%), and $73.9 \%$ were Catholics. The mean age of onset of alcohol consumption in the participants was 16.4 years; $37.8 \%$ had consumed alcohol during the last year, the average number of beverages drunk was 17.9 beverages per consumption occasion. With respect to age when entering $\mathrm{AA}$, the average was 32.9 years, the average for relapses was 2.22 and the mean number of years participating in the program was 18.05 years (Table 1). Table 2 shows that nearly one in every two individuals has had stressful events, pray in private or meditate more or less once a day, and spiritual beliefs are an important part of their lives. The principal value for this group was to be physically and mentally healthy $(65.5 \%)$ and the least important was to be influential (44.4\%).

The following shows the data responding to the study purpose. Positive relation was found between number of days of not drinking alcoholic beverages and age $\left(r^{s}=0.596, p<0.001\right)$ and spirituality $\left(r^{s}=0.289, p<0.001\right)$; negative relation was also found with stressful events $\left(r^{s}=-0.315, p<0.001\right)$. Schooling was not significantly related $\left(r^{s}=-0.052\right.$, $p=0.571)$ nor values $\left(r^{s}=-0.052, p=0.571\right)$ with days of abstinence. Likewise, positive and significant relation was found of spirituality with age $\left(r^{s}=0.214, p=0.02\right)$, schooling in years of studying $\left(r^{s}=0.372, p<0.001\right)$, age on admission to the AA program $\left(r^{s}=0.237\right.$, $p=0.009)$ and the index of values $\left(r^{s}=0.273\right.$, $p=0.003$ ) and negative and significant relation of spirituality with number of relapses $(r=-0.296$, $p<0.001)$ and with the AUDIT index $\left(r^{s}=-0.300\right.$, $p<0.001)$. The multiple linear regression model was significant $\left(F_{[6,118]}=10.44, p<0.001\right)$ and explained $32.5 \%$ of the variance. The variable which finally remained in the model and which had an effect on not drinking alcoholic beverages was age, indicating that the number of days without drinking alcohol in AA participants is explained by the age (standardized Beta $=0.047$, $t=-1.78, p=0.001$ ).

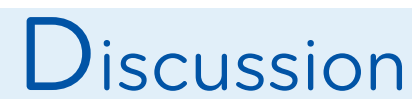

The purpose of this study was to determine the association of personal factors (age, gender, schooling, stressful events, spirituality, and values) and not drinking alcoholic beverages (amount of days without consumption) in alcohol-dependent individuals in recovery process. It was found that the factors identified in alcohol-dependent individuals in recovery process (members of $A A$ groups) who showed a relation with not drinking alcoholic beverages were age, spirituality, and stressful events. Likewise, the factor showing and maintaining a significant effect with not drinking alcoholic beverages was participant age. Age, as a factor associated to not drinking alcoholic beverages, showed that the higher age reported by participants, indicated a greater number of days reported without alcohol consumption. These results differ from that found in the literature, while age increases, there is a greater probability of excessive or dependent alcohol consumption; (22,23) a possible explanation for this is that studies have been conducted in different populations, added to the fact that individuals in the recovery process have received guidance, companionship, and abilities to reject alcohol consumption. ${ }^{(4)}$

In relation to spirituality, it was found that engaging in greater spiritual practices, like praying in private or meditating, increases the number of days without alcohol consumption. This agrees with the literature, given that it mentions that this is an important and useful factor in the long-term recovery success of $A A$ members, by showing that 
Table 1. General characteristics of the 119 individuals in the process of recovering from alcohol dependence

\begin{tabular}{|c|c|c|}
\hline Sociodemographic & $n(\%)$ & Mean \pm SD \\
\hline \multicolumn{3}{|l|}{ Characteristics } \\
\hline \multicolumn{3}{|l|}{ Gender } \\
\hline Male & $103(86.6)$ & \\
\hline Female & $16(13.4)$ & \\
\hline Age & & $46.1 \pm 15.3$ \\
\hline \multicolumn{3}{|l|}{ Marital status } \\
\hline Single & $34(28.6)$ & \\
\hline Married & $52(43.7)$ & \\
\hline Widow (er) & $11(9.2)$ & \\
\hline Divorced & $11(9.2)$ & \\
\hline Common-law & $11(9.2)$ & \\
\hline \multicolumn{3}{|l|}{ Schooling } \\
\hline Primary & $26(21.8)$ & \\
\hline Secondary & $32(26.9)$ & \\
\hline High School & $18(15.1)$ & \\
\hline Technical & $15(12.6)$ & \\
\hline Professional & $23(19.3)$ & \\
\hline Graduate & $5(4.2)$ & \\
\hline \multicolumn{3}{|l|}{ Religion } \\
\hline Catholic & $88(73.9)$ & \\
\hline Christian & $21(17.6)$ & \\
\hline Other & $3(5.9)$ & \\
\hline \multicolumn{3}{|l|}{ None } \\
\hline \multicolumn{3}{|l|}{ Occupation } \\
\hline Employed & $89(69.7)$ & \\
\hline Studies & $8(6.7)$ & \\
\hline Studies and works & $5(4.2)$ & \\
\hline Does not study or work & $7(5.9)$ & \\
\hline Retired & $6(13.4)$ & \\
\hline \multicolumn{3}{|c|}{ Antecedents of alcohol consumption } \\
\hline Age started & & $16.4 \pm 3.7$ \\
\hline \multicolumn{3}{|l|}{ Alcohol consumption } \\
\hline Sometime during their lives & $119(100)$ & \\
\hline Last year & $45(37.8)$ & \\
\hline Last month & $18(15.1)$ & \\
\hline Last week & $5(4.2)$ & \\
\hline \multicolumn{3}{|c|}{ Membership to Alcoholics Anonymous } \\
\hline Age of admission & & $32.9 \pm 11.04$ \\
\hline Years of participation & & $18.05 \pm 11.42$ \\
\hline Average of relapses & & $2.22 \pm 3.4$ \\
\hline
\end{tabular}


Table 2. Stressful events, spirituality, and values of the 119 people in the process of recovering from alcohol dependence

$\begin{array}{lcc}\text { Characteristics } & n(\%) & \text { Mean } \pm \text { DS } \\ \text { Stressful events } & 59(49.6) & 28.8 \pm 19.6 \\ \text { Changes in personal habits } & 58(48.7) & \\ \text { Change in social activities } & 58(48.7) & 64.1 \pm 15.0 \\ \begin{array}{l}\text { Difficulties sleeping } \\ \text { Spirituality }\end{array} & & \\ \text { Spiritual practices } & 50(42) & \\ \text { Pray in private or meditate more or less once a day } & 49(41.2) & 64.1 \pm 15.0 \\ \text { Spiritual beliefs } & & \\ \text { Are an important part of their lives } & 78(65.5) & \\ \text { Values } & 53(44.4) & \\ \text { Most important: being physically and mentally healthy } & & \\ \text { Least important: being influential } & \end{array}$

step 11 of the program ("Sought through prayer and meditation to improve our conscious contact with God as we understood Him, praying only for knowledge of His will for us and the power to carry that out") is related with the duration of the soberness of individuals with alcohol dependence who are in a recovery process. ${ }^{(10-12,24)}$

Stressful events, like changes in personal habits and in social activities, as well as difficulties sleeping showed a negative relationship with days of not drinking alcoholic beverages. A possible explanation is that stressful events have the potential of causing stress and triggering risk behaviors, like alcohol consumption; nevertheless, emotional, cognitive, or behavioral responses produced as consequence of the stressful events depend on the cognitive evaluation performed by the individuals of their personal characteristics and of the modulating variables. ${ }^{(7,25)}$ These results reveal the possible need to manage emotions in participants from AA. Another possible explanation can be that the alcohol-dependent individual is still not prepared for healthy coping, has not completed the AA 12-step program, or has not reached the stage to share the message and it may be difficult for them to face positively the stressful events that can be experimented. ${ }^{(8,25)}$ Finally, it was shown that the factor contributing most to the explanation, showing and maintaining an effect on not drinking alcoholic beverages was participant age, which demonstrates the effectiveness of the AA program, given that people who receive guidance, companionship, and abilities through the program remain sober a greater number of days.

In this sense, it may be concluded that values and spirituality are indispensable tools to favor not drinking alcoholic beverages in people in the process of recovering from alcohol dependence and, in turn, act as personal factors that can favor not drinking alcoholic beverages or sensible consumption in other populations. On the contrary, stressful events are occurrences that place alcohol-dependent individuals in a state of vulnerability to alcohol consumption. Finally, it is considered necessary for nursing professionals to include tools from the AA program, like spirituality and values, to the holistic nursing care provided to alcohol-dependent individuals by virtue of the results observed. 


\section{References}

1. Organización Mundial de la Salud. Alcohol, Datos y Cifras [Internet]. Ginebra: OMS; 2018 [cited 31 ${ }^{\text {st }}$ May 2018]. Available from: http://www.who.int/es/news-room/fact-sheets/detail/alcohol

2. Instituto Nacional de Psiquiatría Ramón de la Fuente Muñiz. Encuesta Nacional de Consumo de Drogas, Alcohol y Tabaco 2016-2017: Reporte de Alcohol [Internet]. Ciudad de México: INPRFM; 2017. Available from: [cited $1^{\text {st }}$ June 2018] https://drive.google.com/file/d/1rMIKaWy34GR51sEnBK2-u2q_BDK9LA0e/view

3. Moreno J. Valores, actitudes hacia el alcohol y consumo en adolescentes varones. Rev. Obs. Filos. 2005; 1(13):195211.

4. Tamers SL, Okechukwu C, Bohl AA, Guéguen A, Goldberg M, Zins M. The impact of stressful events on excessive alcohol consumption in the French population: findings from the GAZEl cohort study. PLoS One. 2014; 9(1):e87653.

5. Coddington RD. The significance of life events as etiologic factors in the diseases of children. II. A study of a normal population. J .Psychosom. Res. 1972; 16(3):205-13.

6. Staton TM, Duval J, Stevens WD, Oser CB. The roles of spirituality in the relationship between traumatic life events, mental health and drug use among African American women. Subst. Use Misuse. 2013; 48(12):1-21.

7. Martins ME, Ribeiro LC, Feital TJ, Baracho RA, Ribeiro MS. Religious-spiritual coping and the consumption of alcoholic beverages in male patients with liver disease. Rev. Esc. Enferm. USP. 2012; 46(6):1341-8.

8. Corrigan P, McCorkle B, Schell B, Kideder K. Religion and spirituality in the lives of people with serious mental illness. Community Ment. Health J. 2003; 39(6):487-99.

9. Reed PG. Theory of Self-Transcendence. In: Smith MJ, Liehr PR. Middle Range Theory of Nursing. $3^{\text {rd }}$ Ed. New York: Springer; 2014.

10. Pillon C, Dos Santos A, Souz AM, Araújo M. Alcohol use and spirituality among nursing students. Rev. Esc. Enferm. USP. 2011; 45(1):98-105.

11. Haber JR, Grant JD, Jacob T, Koenig B. Alcohol milestones, risk factors and religion/spirituality in young adult women. J. Stud. Alcohol Drugs Suppl. 2012; 73(1):34-43.

12. Rodríguez LA, Alonso BA, Alonso MM, Alonso MT, Oliva NN, Armendáriz. NA. Valores terminales, valores instrumentales y consumo de alcohol y tabaco en estudiantes de preparatoria. Enferm. Comunitaria. 2015; 11(1):1-7.

13. Anderson P, Gual A, Colon J. Alcohol y Atención Primaria de la salud: informaciones clínicas básicas para la identificación y el manejo de riesgos y problemas [Internet]. Washington DC: Organización Panamericana de la Salud; 2008. [cited 12 ${ }^{\text {th }}$ Mar 2018]. Available from: http://www.who.int/substance_abuse/publications/alcohol_ atencion_primaria.pdf

14. Alonso CM, Álvarez BJ, López GK, Rodríguez AL, Armendáriz NA. Factores de riesgo personales, psicosociales y consumo de alcohol en mujeres adultas. Investig. Enferm. 2009; 11(1):97-115.

15. Bigwan El, Ohaeri MC, Elijah D, Wakjissa FD, Sheyin, Z. Some risk factors associated with acid-alcohol-fast bacilli in patients with suspected pulmonary tuberculosis. S. Afr. J. Infect. Dis. 2014; 8(2):22-6.

16. Rodríguez AL, De la Garza GL, Rodríguez DG, Alonso, CM, Guzmán FF. Valores y consumo de alcohol y tabaco en jóvenes universitarios. Rev. Enf. Herediana. 2015; 8(2):62-9.

17. Lema SL, Varela AM, Duarte AC, Bonilla GM. Influencia familiar y social en el consumo de alcohol en jóvenes universitarios. Rev. Fac. Nac. Salud Pública. 2011; 29(3):264-71.

18. Holmes TH, Rahe R. The Social Readjustment Racing Scale. J. Psychosom. Res. 1967; 11:213-8.

19. Hinojosa L, Alonso MM, Castillo Y. Autoeficacia percibida y consumo de alcohol en trabajadores de la salud. Rev. Enferm. Inst. Mex. Seguro Soc. 2012; 20(1):19-25.

20. Schwartz SH, Bilsky W. Towards a universal psychological structure of human values. J. Pers. Soc. Psychol. 1987; 53(3):550-62. 
21. De la Fuente R, Kershenobich D. El alcoholismo como problema médico. Rev. Fac. Med. UNAM. 1992; 35(2):47-51.

22. Guzmán FF, Pedrao LJ, López GK, Rodríguez AL, Esparza AS. Trastornos por consumo de alcohol en adolescentes y jóvenes marginales de bandas juveniles de México. Esc. Anna Nery Rev. Enferm. 2007; 11(4):611-8.

23. Connors GJ, Tonigan JS \& Miller WR. A measure of religious background and behavior for use in behavior change research. Psychol. Addict Behav. 1996; 10(2):90-6.

24. Pérez MA, Redondo OM, Mesa GI, Jiménez PI, Martínez FM, Pérez MR. Motivaciones para el consumo de alcohol entre adolescentes de un instituto urbano. Rev. Aten. Prim. 2010; 42(2):604-11.

25. Ávila CM, Heredia AM, Gómez ME \& Martínez PL. (2006). Confiabilidad interna y estabilidad temporal del cuestionario de sucesos de vida para adolescentes en estudiantes mexicanos. Enseñanza. Investig. Psicol. 2006; 11(1):97-113. 